\title{
Design Strategy of Vocational School Of Fine Arts With PhSycological Architecture Studies
}

\section{Strategi Desain Sekolah Menengah KeJUruan Seni Rupa Dengan Penerapan Psikologi Arsitektur}

\author{
Natasia Anggi Laxmita ${ }^{1 *}$, Suparno $^{2}$, Tri Yuni Iswati ${ }^{3}$ \\ Program Studi Arsitektur, Fakultas Teknik, Universitas Sebelas Maret ${ }^{1}$ \\ natasia.anggi@ student.uns.ac.id* \\ Program Studi Arsitektur, Fakultas Teknik, Universitas Sebelas Maret ${ }^{2}$ \\ Program Studi Arsitektur, Fakultas Teknik, Universitas Sebelas Maret ${ }^{3}$
}

\begin{abstract}
Education is a such a priority and its necessary for student to improve their skill to be able to employe themself for a job rivals. Because in this growing era demands more competent students are needed to be considered in the world of work, especially in a fine arts school. This study aims to know how the psychology of architecture applied in the vocational school of fine art. Psychological architecture is a field of study that studies the relationship between built environment and human behavior, which mutually affect one another. The built environment and human behaviour able to develop their own potential, so that the environment will greatly affect the development of student's potential. This design strategy is located in Klaten. The research method used is applied research, through the data collection which then concluded and become the guidance in the design analysis. The application of psychological architecture in this building is done through the design in accordance with the user's characteristics, by connecting the characteristics and theories of psychological architecture. The result of application can be seen in users, activities, site, space, lay out arrangement and also the appearance of interior and exterior. The analysis process that apply psychology of architecture study can give a result of school design which give comfort when the user doing the activity.
\end{abstract}

Keywords: psychological architecture, the vocational school of fine art, design strategy

\section{PENDAHULUAN}

Pada dasarnya manusia membutuhkan pendidikan dalam kehidupannya. UndangUndang Dasar Negara Republik Indonesia Tahun 1945 Pasal 31 ayat (1) menyebutkan bahwa setiap warga negara berhak mendapat pendidikan, dan ayat (3) menegaskan bahwa Pemerintah mengusahakan dan menyelenggarakan satu sistem pendidikan. Sarana dalam mendapatkan pendidikan adalah Sekolah. Sekolah Menengah Kejuruan (SMK) adalah salah satu bentuk satuan pendidikan formal yang menyelenggarakan pendidikan kejuruan pada jenjang pendidikan tingkat menegah sebagai lanjutan SMP/MTS atau sederajatnya.

Seiring berjalannya waktu, Pemerintah Indonesia semakin gencar membuat program dalam rangka mengurangi pengangguran terutama di kalangan remaja. Setiap tahun diperkirakan $95 \%$ golongan remaja tersebut siap memasuki dunia kerja, namun hanya $12 \%$ saja yang dapat terserap. Hal ini disebabkan karena kendala lapangan pekerjaan yang minim dan kurangnya ketrampilan yang dimiliki oleh calon tenaga kerja. Hal ini perlu menjadi 
perhatian agar lulusan SLTA atau sederajat tidak hanya bekerja sebagai pegawai saja, namun harus memiliki kualitas SDM dan keterampilan yang mumpuni agar dapat bersaing untuk mampu menciptakan lapangan pekerjaan sendiri. Salah satu upaya pemerintah Indonesia yakni peningkatan mutu pendidikan vokasi yang didukung oleh kolaborasi antara pemerintah pusat dengan pemerintah daerah (pemda).

Klaten merupakan salah satu kota yang ditetapkan sebagai kota vokasi di Indonesia. Sehingga pemerintah kabupaten / kota berkewajiban melaksanakan dan mengembangkan pendidikan kejuruan dalam rangka mendukung kegiatan vokasi. (Peraturan Gubernur Jawa Tengah Nomor 56 Tahun 2013 Tahun 2013 Pasal 9 tentang Petunjuk Pelaksanaan Peraturan Daerah Provinsi Jawa Tengah Nomor 4 Tahun 2012 Tentang Penyelenggaraan Pendidikan).

Perencanaan dan perancangan sekolah memerlukan sebuah metode desain agar persoalan - persoalan dapat terselesaikan secara arsitektural. Penerapan psikologi arsitektur dipilih sebagai pendekatan dalam proses perencanaan dan perancangan sekolah menengah kejuruan seni rupa karena perancangan akan disesuaikan dengan karakteristik user, sehingga akan menghasilkan output berupa rancangan bentuk dan setting ruang. Salah satu faktor yang mendukung kriteria sekolah yaitu melalui perancangan bangunan yang akomodatif, diantaranya aspek psikologis. Dalam perancangan arsitektur, cara mengakomodasi aspek psikologis dapat melalui penerapan psikologi arsitektur.

Psikologi Arsitektur adalah sebuah bidang studi yang mempelajari hubungan antara lingkungan binaan dengan psikologi dan perilaku manusia, dimana keduanya saling mempengaruhi satu sama lainnya, (Halim, 2005). Unsur Psikologi Arsitektur yang digunakan pada strategi desain untuk pembentukan suasana, yakni: unsur bentuk, unsur warna, unsur tekstur dan unsur proporsi. Ilmu psikologi dalam menciptakan lingkungan binaan, yang mampu menghasilkan respon berupa perilaku yang diingkinkan berupa perancangan yang sesuai dengan karakteristik anak (Munandar \& Utami, 2002).
Psikologi arsitektur menjadi penting untuk digunakan sebagai metoda pendekatan desain pada sebuah bangunan pendidikan, karena memiliki daya dukung ilmu psikologi dalam menciptakan lingkungan binaan, yang mampu menghasilkan respon berupa perilaku yang diingkinkan dan sesuai dengan psikologis pengguna. Oleh karenanya, penerapan psikologi arsitektur dapat mendukung tercapainya sarana dan prasarana bangunan sekolah yang dibutuhkan sebuah sekolah menengah kejuruan.

\subsection{Teori Psikologi Arsitektur}

Psikologi Arsitektur adalah sebuah bidang studi yang mempelajari hubungan antara lingkungan binaan dengan psikologi dan perilaku manusia, dimana keduanya saling mempengaruhi satu sama lainnya (Halim, 2005)

Terdapat empat isu pokok yang menghubungkan disiplin ilmu arsitektur dan psikologi, yaitu : kepribadian bangunan, arketipe bangunan, anatomi bangunan dan karakter bangunan. manusia (Haryadi \& Setiawan, 2014).

Ada istilah dalam psikologi yang merujuk pada karakter kepribadian spesifik seeorang, yakni istilah "introvert" dan "ekstrovert". Karakter tersebut di artikan dalam bahasa arsitektur sebagai sifat tertutup (enclosure) maupun sifat terbuka (openess) dari sebuah bangunan.

Arketipe diartikan sebagai bentuk pemikiran universal seseorang terhadap bangunan. Konsep sekolah yang edukatif dan kreatif harus tercermin dalam bangunan agar mindset seseorang mengenai citra kreatif dapat terbentuk ketika seseorang melihat bangunan.

Anatomi fisik digambarkan melalui obyek fisik dari psikologi adalah manusia yang terdiri dari tiga bagian utama, yaitu kepala, badan dan kaki. Untuk itu, bangunan juga harus mampu merefleksikan tiga unsur utama tersebut. Untuk karakter bangunan dapat dikategorikan menjadi bangunan dengan citra feminim maupun maskulin. Unsur Psikologi Arsitektur yang digunakan pada strategi desain untuk pembentukan suasana, yakni: unsur bentuk, unsur warna, unsur tekstur, unsur proporsi.

\subsection{Standar Sekolah Menengah Seni Rupa}

Sekolah menengah kejuruan seni rupa adalah bentuk satuan pendidikan menengah yang 
merupakan lanjutan dari SMP, MTs. , atau bentuk lain yang sederajat dan mempersiapkan peserta didik untuk memasuki lapangan kerja dengan berbekalkan keahlian dalam bidang seni rupa itu sendiri. Satu SMK/MAK memiliki sarana dan prasarana yang dapat melayani minimum 3 rombongan. Dalam Peraturan Menteri Pendidikan Nasional Nomor 40 Tahun 2008 Tentang Standar Sarana Dan Prasarana Sekolah Menengah Kejuruan/Madrasah Aliyah Kejuruan (SMK/MAK) sebuah SMK/MAK sekurang-kurangnya memiliki prasarana, diantaranya: kelompok ruang pembelajaran umum, ruang penunjang, ruang pembelajaran khusus. Kelompok ruang terdiri dari ruang kelas, perpustakaan, labroatorium komputer. Kelompok ruang penunjang terdiri dari ruang guru, ruang pengelola, ruang konseling, ruang UKS, ruang organisasi kesiswaan, toilet, gudang, tempat bermain olahraga. Sedangkan Kelompok pembelajaran khusus terdiri dari ruang-ruang praktik masing-masing program keahlian.

Sekolah menengah kejuruan seni rupa yang dirancang untuk mengakomodasi kebutuhan belajar mengajar sebagai sarana bangunan pendidikan dalam bidang Seni Rupa yang diharapkan menjadi stimulan kegiatan yang kreatif, inovatif dan terampil. Kajian - kajian psikologi arsitektur dalam perancangan bangunan sekolah menengah kejuruan seni rupa di Klaten diterapkan secara menyeluruh pada persoalan - persoalan sehingga tercapai rancangan yang memperhatikan aspek fungsional dan aspek psikologis pengguna.

\section{METODE}

Objek rancangan sekolah menengah seni rupa dirancang dengan menerapkan kajian - kajian dalam teori psikologi arsitektur. Dalam tahap perencanaan dan perancangan bangunan sekolah menengah kejuruan seni rupa diperlukan sebuah metode sebagai landasan pengerjaan - pengerjaan mulai awal sampai dengan selesainya rancangan sekolah menengah kejuruan seni rupa.

Metode survei dengan pengumpulan data primer dan sekunder. Pengumpulan data primer berupa data lapangan yang didapat dengan cara pengamatan dan wawancara, sedangkan data sekunder terdiri dari data pustaka yang didapatkan melalui literatur baik pustaka maupun internet kemudian data tersebut yang akan digunakan dalam menyelesaikan permasalahan dan persoalan.

Dalam proses analisis data dapat dikelompokkan menjadi data non-fisik dan data fisik. Data non-fisik menganalisis aktivitas pengguna dan kebutuhan ruang sehingga menghasilkan pola hubungan ruang. Data fisik berisi analisi tapak, bentuk, struktur, utilitas dan peraturan daerah yang menghasilkan zoning.

\subsection{Prosedur Penelitian}

Dalam tahapan ini akan menggunakan prinsip desain psikologi arsitektur. Mengubah pendekatan yang berorientasi pada solusi menjadi pendekatan yang berorientasi pada masalah, yang lebih menekankan identifikasi dan analisis masalah secara deskriptif, sebelum menetapkan sintesis solusi. Model perancangannya berupa suatu siklus desain dengan adanya umpan balik dan umpan maju pada setiap tahapan.

Tahapan analisis akan dikelompokkan berdasarkan: program fungsional, performansi dan arsitektural. Program fungsional bertujuan untuk mengidentifikasi penggunaan bangunan Sekolah Menengah Seni Rupa (selanjutnya ditulis SMSR) yang direncanakan yaitu pengguna, kegiatan pengguna, alur kegiatan, dan lain-lain. Program performansi bertujuan untuk menerjemahkan secara skematik kebutuhan calon pengguna SMSR di Klaten. Hal ini membahas tentang persyaratan kinerja setting ruang yakni kebutuhan ruang, persyaratan ruang dan program ruang dalam bangunan. Analisis arsitektural bertujuan menggabungkan dari kedua analisis sebelumnya (fungsional dan performansi). Dalam hal ini akan dianalisis masalah pengolahan site, massa, citra bangunan, tampilan, peruangan, utilitas dan struktur bangunan yang sesuai dengan kebutuhan pengguna dan persyaratan yang ada dengan mempertimbangkan psikologis pengguna. Sehingga dari konsep pra-desain terebut akan menemukan keputusan desain dalam perancangan bangunan Sekolah Menengah Seni Rupa dengan pendekatan psikologi arsitektur di Klaten. 


\subsection{Penyusunan Penelitian}

Tahap penyusunan penelitian merupakan penggabungan hasil terbaik yang sudah dikaji pada tahap pemograman arsitektural. Hasil dari tahap pemograman arsitektural akan diolah dan diterjemahkan ke dalam bentuk ungkapan fisik yang dikehendaki sesuai dengan daya kreatif perancang.

\subsection{Strategi Desain}

Tahap strategi desain akan melakukan studi lanjut mengenai konsep - konsep yang sudah didapatkan dan diolah menjadi sebuah desain skematik yaitu desain kasar yang memuat gambaran umum dari bangunan yang akan direncanakan dan dirancang.

\section{HASIL DAN PEMBAHASAN}

Kebutuhan ruang pada sekolah menengah kejuruan seni rupa didasarkan pada kegiatan pelaku - pelaku kegiatan yang mungkin terlibat dalam sekolah menengah kejuruan seni rupa , karakteristik kegiatan, dan juga pola kegiatan.

Pelaku - pelaku kegiatan yang mungkin terlibat pada sekolah menengah kejuruan seni rupa antara lain peserta didik, pengunjung, guru, tenaga kependidikan dan pengelola sekolah Karakteristik kegiatan pada peserta didik mencakup kegiatan pembelajaran dan kegiatan yang menggunakan fasilitas bersama. Pada orang tua dan rekan peserta didik mencakup kegiatan berkunjung. Pada pengelola sekolah mencakup kegiatan bekerja administrasi dan bekerja pengelolaan dan pemeliharaan bangunan.

Kebutuhan ruang dikelompokkan menjadi: kegiatan penerimaan, kegiatan utama, kegiatan organisasional, kegiatan penunjang, kegiatan pengelola, kegiatan servis dan perawatan bangunan. Kegiatan penerimaan memiliki kriteria mencakup main entrance dan information desk. Kegiatan utama terdiri dari ruang kelas dan ruang praktikum. Kegiatan organisasional meliputi ruang serbaguna atau auditorium, ruang konsultasi, ruang rapat. Untuk kegiatan penunjang berupa galeri pameran dan lapangan olahraga. Kegiatan pengelola berupa ruang-ruang administrasi dan pihak-pihak pengelola. Kegiatan servis dan perawatan bangunan mecakup ruang: lavatory, gudang, ruang mekanikal elektrikal, pos satpam, loading dock. Setelah didapatkan kebutuhan ruang kemudian menentukan kualitas ruang. Kualitas ruang didasarkan pada psikologis pengguna.

Kualitas ruang dicapai dengan strategi penerapan unsur psikologi arsitektur. Secara umum kualitas yang dikehendaki pada ruang dan strategi pencapaian kualitas lingkungan tersebut adalah ruang memiliki kesan memberi semangat dan suasana menyenangkan pada area pembelajaran dengan mengaplikasikan warna yang memiliki kesan semangat, seperti orange, kuning, biru dan hijau. Ruang memiliki kesan kuat dengan tekstur karakter dengan menggunakan perpaduan material beton, baja, kaca, batu alam, marmer dan kayu . Ruang memiliki kualitas skalatis pada masing-masing zona dengan menggunakan skala normal pada ruang kelas, skala monumental pada zona pendukung seperti perpustakaan, masjid, hall, ruang pameran. Ruang memiliki kualitas penunjang psikologis seperti ketenangan dan privasi dengan meletakan ruang pada tempat yang jauh dari kebisingan dan menggunakan material bata ringan sebagai pembentuk ruang. Kualitas ruang memiliki pencahayaan dan penghawaan yang baik dicapai dengan pemberian pencahayaan dan penghawaan alami dengan jendela dan curtain wall dan pencahayaan buatan dengan lampu, dan penghawaan buatan dengan $\mathrm{AC}$,

Kualitas ruang digunakan sebagai dasar penyusunan organisasi ruang seperti pada Gambar 1 berdasarkan kualitas ruang yang dikehendaki. Selain itu organisasi ruang mempertimbangkan hubungan kedekatan antar ruang.

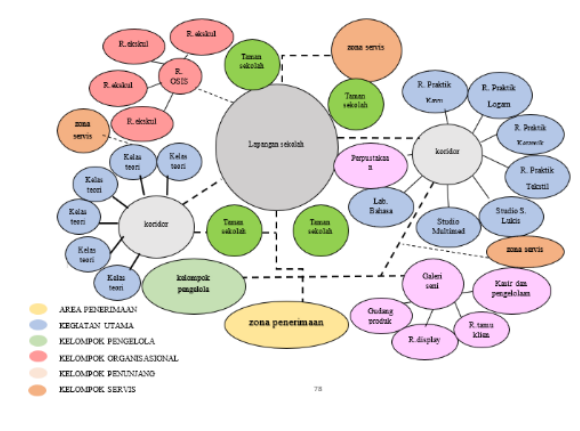

Gambar 1. Pola Hubungan Ruang Sekolah menengah kejuruan seni rupa 
Setelah itu ditentukan luas dan besaran ruang yang perhitungannya mempertimbangkan kebutuhan perabot dan sirkulasi pada ruang. Tahap - tahapan perhitungan luas dan besaran ruang pada sekolah menengah kejuruan seni rupa yaitu dengan memperhatikan perabotan, sirkulasi dan zona personal. Untuk perabotan hal-hal yang harus diperhatikan adalah mendaftar perabot yang mungkin digunakan dan jumlah perabot pada suatu ruang, menghitung luas perabot berdasarkan antropometri, menjumlah luas perabot dengan luas sirkulasi sehingga didapatkan luas ruang menentukan zona personal yang mungkin terjadi pada suatu ruang berdasarkan kegiatan yang diwadahi ruang tersebut dan jumlah kapasitas ruang yang dikehendaki. Untuk menghitung luas sirkulasi pada ruang berdasarkan zona spasial dan kapasitas jumlah orang dalam ruang, kemudian mengalikan luas ruang dengan tinggi dari lantai ke langit - langit untuk mendapatkan besaran ruang. Luas dan besaran ruang dapat dilihat pada Tabel 1 .

Tabel 1. Luas dan Besaran Ruang Sekolah menengah kejuruan seni rupa

\begin{tabular}{|l|l|}
\hline Kel. Penerima & $\pm 1399 \mathrm{~m} 2$ \\
\hline Kel. Utama & $\pm 9291,6 \mathrm{~m} 2$ \\
\hline Kel. Organisasional & $\pm 202 \mathrm{~m} 2$ \\
\hline Kel. Ruang pendukung & $\pm 691,4 \mathrm{~m} 2$ \\
\hline Kel. R. pengelola & $\pm 339 \mathrm{~m} 2$ \\
\hline Kel. R. Servis & $\pm 180 \mathrm{~m} 2$ \\
\hline Total kebutuhan ruang & $\pm 12309,4 \mathrm{~m} 2$ \\
\hline
\end{tabular}

Jumlah lantai pada bangunan SMSR dirancang menjadi dua lantai, dengan analisis sebagai berikut,

Tabel 2. Analisis Lapis Bangunan Sekolah menengah kejuruan seni rupa

\begin{tabular}{|l|l|l|}
\hline $\begin{array}{l}\text { Nama } \\
\text { Kelompok } \\
\text { Ruang }\end{array}$ & $\begin{array}{l}\text { Jumlah } \\
\text { Lantai }\end{array}$ & Luasan $(\mathrm{m} 2)$ \\
\hline Penerima & 2 & $\pm 688,5 \mathrm{~m} 2$ \\
\hline $\begin{array}{l}\text { Kegiatan Utama } \\
\text { KBM }\end{array}$ & 3 & $\pm 3097,2 \mathrm{~m} 2$ \\
\hline Pengelola & 2 & $\pm 339 \mathrm{~m} 2$ \\
\hline Organisasional & 1 & $\pm 202 \mathrm{~m} 2$ \\
\hline Penunjang & 1 & $\pm 691,4 \mathrm{~m} 2$ \\
\hline Servis & 1 & $\pm 180 \mathrm{~m} 2$ \\
\hline Luasan Lantai Dasar $=\mathbf{5 9 1 8 , 1} \sim \mathbf{6 0 0 0}$ \\
\hline
\end{tabular}

Luas site yang dibutuhkan :

Rumus Luas Site

$=100 / \mathrm{BC} \times$ Luas lantai dasar

$=100 / 40 \times 6000$

$= \pm 15000 \mathrm{~m} 2$

\subsection{Tapak}

Strategi pemilihan tapak didasarkan pada peraturan dan psikologis pengguna yang memiliki kecenderungan memilih sekolah yang mudah di jangkau dari segala aspek. Tapak terpilih (lihat Gambar 2 dan Gambar 3) yaitu berada di Jalan Merbabu , kecamatan Klaten Tengah dan memiliki luas lahan $\pm 15.000 \mathrm{~m}^{2}$ dengan batas - batas pada sebelah utara Stadion Trikoyo , timur pemukiman, selatan kodim , dan barat area fasilitas pendidikan seperti toko alat tulis dan tempat bimbingan belajar

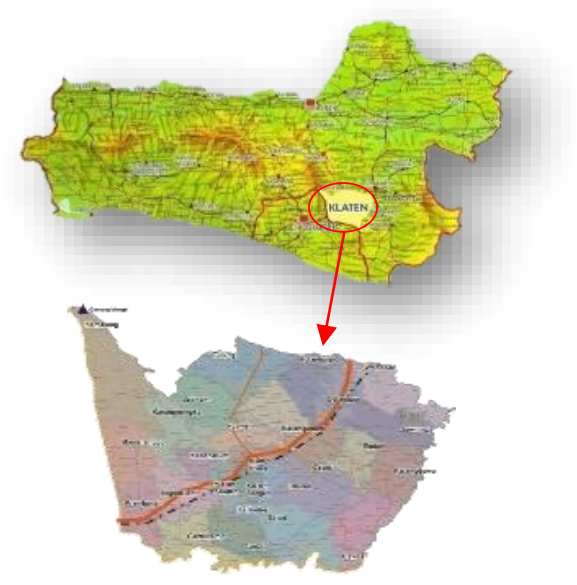

Gambar 2. Peta Kabupaten Klaten Sumber: Klaten Dalam Angka 2017, BPS Kab.
Klaten

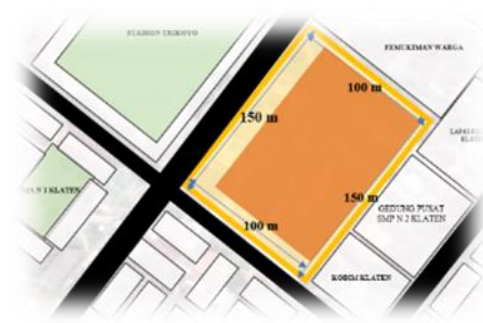

Gambar 3. Tapak Terpilih

Pengolahan tapak terhadap pencapaian seperti pada Gambar 4, mempertimbangkan psikologis dengan: jumlah lebih dari satu untuk menghindari penumpukan antrian kendaraan sehingga tidak mempengaruhi emosi pelaku kegiatan saat terburu-buru dan kemudahan pencapaian dari sisi orang datang (dari segala arah) sehingga orang nyaman dan tidak kesulitan. 


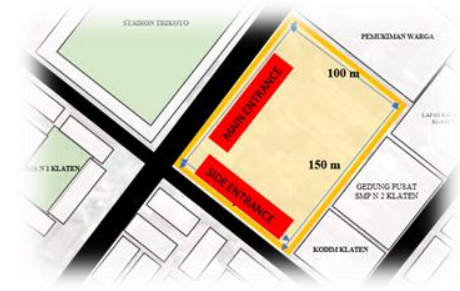

Gambar 4. Respon Main Entrance dan Side Entrance pada Tapak

Pengolahan tapak terhadap kebisingan mempertimbangkan sumber kebisingan, intensitas kebisingan, dan zona yang membutuhkan ketenangan. Strategi perancangannya yaitu dengan memberikan tembok pagar dan vegetasi untuk mengurangi kebisingan pada sebelah utara, barat, dan selatan tapak.

Pengolahan tapak terhadap arah lintas matahari dan arah hembus angin mempertimbangkan sifat radiasi dan sinar matahari serta arah dan sifat hembusan angin. Strategi perancangannya yaitu tapak sebelah utara dijadikan arah orientasi bangunan, timur diberi vegetasi, barat diberi vegetasi, dan selatan diberi vegetasi.

Pengolahan tapak terhadap sirkulasi dan zonasi mempertimbangkan perilaku pengguna dan kualitas lingkungan zona. Sirkulasi kendaraan mempertimbangkan pola sirkulasi kendaraan yang mungkin terjadi didalam tapak. Zonasi mempertimbangkan privasi sehingga dilettakan pada bagian belakang bangunan. Sehingga pengolahan tapak terhadap sirkulasi dapat dilihat pada Gambar 5.

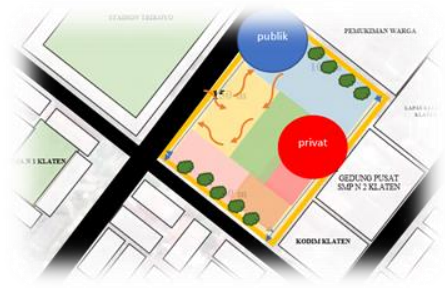

Gambar 5. Respon Pengolahan Tapak

\subsection{Tampilan Bangunan}

Strategi perancangan bentuk dasar ruang dan bentuk dasar massa bangunan menerapkan kajian arsitektur perilaku persepsi bentuk dan ruang. Bentuk dasar ruang ditetapkan bentuk segi empat lihat Gambar 6 dan bentuk dasar massa ditetapkan bentuk kubus atau balok karena bentuk tersebut memberikan persepsi yang mudah dipahami, memberikan efek nyaman, dan aman (Avishag Shemesh, Moshe Bar, 2015).

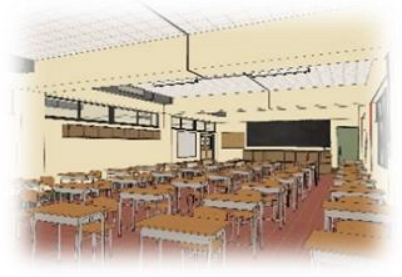

Gambar 6. Penerapan bentuk segi empat pada ruang

Strategi perancangan jenis koridor yang digunakan pada sekolah menengah kejuruan seni rupa mempertimbangkan kualitas lingkungan fisik dan kualitas lingkungan psikologis. Jenis koridor ditetapkan jenis koridor single loaded open coridor (lihat Gambar 7) karena memungkinkan terbentuknya lingkungan yang open view, memungkinkan terjadinya ventilasi silang, maksimalisasi cahaya alami masuk.
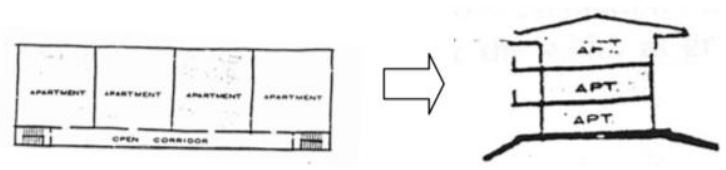

Gambar 7. Penerapan koridor jenis single loaded open coridor

Strategi perancangan warna ruang menerapkan kajian arsitektur perilaku kualitas lingkungan psikologis dan mempertimbangkan pengaruh warna terhadap pengamat yang disesuaikan dengan karakteristik kegiatan pada ruang. Secara umum karakteristik ruang dan strategi perancangannya adalah suasana netral direspon dengan warna abu-abu, suasana nyaman dengan warna coklat muda/krem, suasana semangat dengan warna orange, dan suasana sejuk dengan warna biru muda seperti pada Gambar 8 .

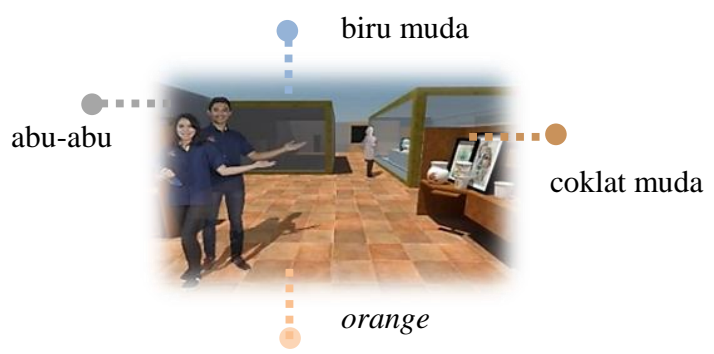

Gambar 8. Penerapan warna - warna tertentu untuk memberikan suasana tertentu 
Tekstur dapat mempengaruhi karakter objek. Ada 2 macam tekstur yaitu tekstur kasar yang memberi kesan berani, aktif, riil (dapat diraba) dan tekstur halus yangmemberi kesan lembut, tenang, feminim dan pasif.

Tekstur diaplikasikan berdasarkan zona kegiatan lihat Gambar 9. Perpaduan antara tekstur halus dan kasar seperti beton, baja, kaca, batu alam, marmer dan kayu menimbulkan kesan tegas dan alami akan dipakai untuk menambah estetika dan menimbulkan kesan rileks untuk pskilogis pengguna.

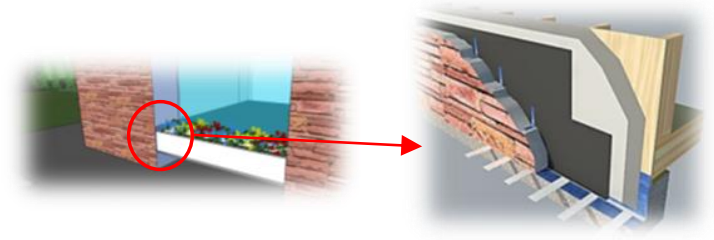

Gambar 9. Penerapan tekstur dengan pemilihan material

Proporsi di dalam ruang mempengaruhi psikologis orang di dalamnya. Ruang yang berdinding terlalu tinggi bila dibandingkan dengan luasnya akan berkesan sempit dan membuat tertekan. Ruang dengan dinding rendah akan mengurangi privasi orang di dalamnya. Ruang dengan plafon rendah memunyai sifat mengundang. Perbedaan tinggi dan bentuk memberikan perbedaan visual atas zona - zona dari ruang yang lebih luas dan orang dapat merasakan perbedaan aktivitas di dalam ruang tersebut. Perbedaan luas dan tinggi ruangan tidak dapat diukur dengan pasti karena banyak faktor yang terkait di dalamnya seperti pemakai ruang, ukuran prabotan yang ada, warna dan tekstur ruang.

\subsection{Struktur}

Pemilihan material struktural dan sistem struktur dilakukan dengan penerapan kajian psikologis arsitektur mengenai rasa aman. Selain itu terdapat pertimbangan pertimbangan lain dalam pemilihannya baik material struktural maupun sistem struktur.

Material struktural pada bangunan sekolah menengah kejuruan seni rupa menggunakan material beton bertulang baja karena mampu menahan beban horizontal dan vertikal serta tahan api dan karat, mudah diolah dalam bentuk dan warna, dan murah dalam pelaksanaan dan perawatannya.
Sedangkan sistem struktur yang digunakan mempertimbangkan kekuatannya dalam menahan beban, kemudahan dalam pembentukan tampilan bangunan, dan pelaksanaan yang mudah serta biaya yang murah.

Sistem struktur upper struktur menggunakan atap limasan dan pelana sesuai dengan standard. Sistem struktur supper struktur menggunakan struktur rangka. Sistem struktur sub struktur menggunakan pondasi batu kali dan pondasi tapak.

\subsection{Utilitas}

Pemilihan sistem utilitas bangunan sekolah menengah kejuruan seni rupa secara umum menerapkan kajian arsitektur perilaku: setting perilaku dan kualitas lingkungan fisik.

Transportasi vertikal pada bangunan sekolah menengah kejuruan seni rupa menerapkan sistem tangga. Tangga biasa dirancang dengan mempertimbangkan antropometri sehingga tercapai kenyamanan bagi penggunanya dengan lebar anak tangga $30 \mathrm{~cm}$ dan tinggi tiap anak tangga adalah $19 \mathrm{~cm}$.

Bangunan sekolah menengah kejuruan seni rupa dilengkapi dengan pencahayaan buatan berupa lampu LED berwarna putih untuk memberikan kenyamanan bagi mahasiswi sebagai pengguna dalam melakukan berbagai macam kegiatan.

Bangunan sekolah dilengkapi dengan sistem pemipaan yang akan dibedakan menjadi sistem air bersih, sistem pemadam sprinkler, dan sistem air buangan. Sistem air buangan akan terdiri dari air kotor, air bekas, dan air hujan

\section{Hasil Akhir}

Bangunan Sekolah Menengah Kejuruan Seni Rupa ini menerapkan prinsip psikologis arsitektur dilihat dari dua sisi. Yang pertama, dari sisi eksterior (lihat Gambar 10) maka pengguna diluar bangunan akan memiliki persepsi dengan memperhatikan karakter bangunan, kepribadian bangunan, anatomi bangunan dan arketipe. 


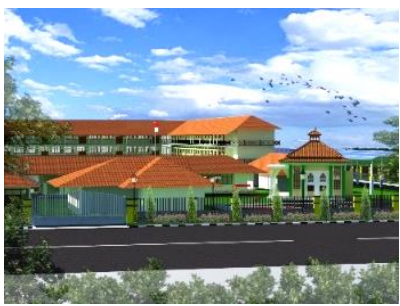

Gambar 10. Perspektif eksterior Sekolah Menengah Seni Rupa

Penggunaan sculpture pada bagian fasad bangunan lihat Gambar 11 digunakan untuk memperkuat kesan karakter bangunan sekolah menengah kejuruan seni rupa. Kemudian adanya pagar yang membentang di sekeliling bangunan menunjukkan bahwa bangunan ini memiliki kepribadian semi-introvert.

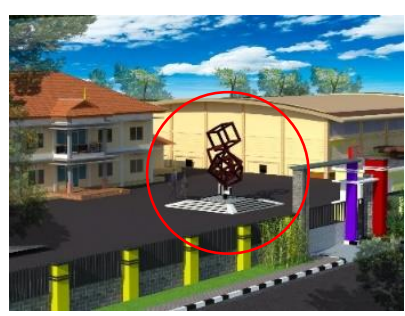

Gambar 11. Karakter bangunan Sekolah Menengah Kejuruan Seni Rupa

Untuk pengguna di dalam bangunan akan memiliki persepsi bangunan melalui interior dengan memperhatikan psikologis siswa/murid dengan cara membentuk suasana melalui warna, tekstur, proporsi dan skala. Warna yang digunakan adalah warna yang bersifat netral dan memiliki kesan membangun semangat yakni warna abu-abu, putih dan kuning, seperti pada Gambar 12. Proporsi dan skala ruangan ditunjukkan dengan tinggi plafon yang tidak terlalu jauh sehingga menimbulkan kesan intim diantara murid dan guru atau sebaliknya.

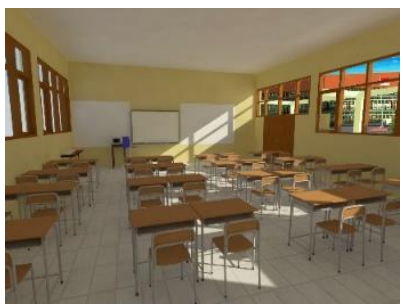

Gambar 12. Interior bangunan Sekolah Menengah Kejuruan Seni Rupa

\section{KESIMPULAN}

Sekolah menengah kejuruan seni rupa yang dirancang untuk mengakomodasi kebutuhan belajar mengajar sebagai sarana bangunan pendidikan dalam bidang Seni Rupa yang diharapkan menjadi stimulan kegiatan yang kreatif, inovatif dan terampil. Perencanaan dan perancangan sekolah memerlukan sebuah metode desain agar persoalan - persoalan dapat terselesaikan secara arsitektural. Penerapan psikologi arsitektur sebagai pendekatan dalam proses perencanaan dan perancangan sekolah menengah kejuruan seni rupa memperhatikan beberapa unsur psikologi arsitektur berupa kesan terhadap bangunan dan pembangunan suasana melalui detail-detail warna, tekstur, bentuk, proporsi yang tentunya disesuaikan dengan karakteristik user, sehingga akan menghasilkan output berupa rancangan bentuk dan setting ruang sesuai dengan kriteria bangunan pendidikan yang memperhatikan aspek fungsional dan aspek psikologis pengguna.

\section{REFERENSI}

Avishag Shemesh, Moshe Bar, Y. J. G. (2015). Space And Human Perception - Exploring Our Reaction To Different Geometries Of Spaces. Computer-Aided Architectural Design Research In Asia Caadria 2015, 20(Computer-Aided Architectural Design), 10.

Harris, C. M. (2006). Dictionary Of Architecture \& Construction. New York: Mcgraw-Hill.

Haryadi, \& Setiawan, B. (2014). Arsitektur Lingkungan Dan Perilaku: Suatu Pengantar Ke Teori, Metodologi, Dan Aplikasi (2nd Ed.). Yogyakarta: Gadjah Mada University Press.

Halim, D. (2005). Psikologi Arsitektur: Pengantar Kajian Lintas Disiplin. Jakarta: Pt Grasindo.

Munandar, \& Utami. (2002). Kretivitas Dan Keterbakatan: Strategi Mewujudkan Potensi Kreatif Dan Bakat. Jakarta: Gramedia Pustaka Utama.

Tri Suci H. (2017). Penerapan Psikologi Arsitektur Pada Fasilitas Pendidikan Anak Usia Dini Dan Sekolah Dasar Di Kota Surakarta. Arsitektur, 15.

Ariani Nurfakhirah. (2017). Penerapan Pendekatan Psikologi Arsitektur Pada Sekolah Luar Biasa Tunarungu (SLB Tipe B) Di Kota Bekasi.Arsitektura, 15. 